\title{
Research on Current Situation and Countermeasures of Sichuan New Energy Automobile Industry Development
}

\author{
Tao Yang ${ }^{1,2}$, Yinghua Liao ${ }^{1,2, *}$ and Dehui Zhao ${ }^{1,2}$ \\ ${ }^{1}$ Sichuan University of Science \& Engineering, Sichuan Zigong 643000, China; \\ ${ }^{2}$ Sichuan Provincial Key Laboratory of Process Equipment and Control Engineering, Zigong, Sichuan 643000, China \\ ${ }^{*}$ Corresponding author
}

\begin{abstract}
Based on the situation of the development of new energy automobile industry in Sichuan Province, this article analyzes the problems in the development, demonstration and popularization of new energy vehicle industry. Combining Sichuan's "13th Five-Year Plan" strategic emerging industries planning, it puts forward three Countermeasures and Suggestions to speed up the development of new energy automobile industry in Sichuan Province. First, break through the core technologies under the guidance of government and cooperation between schools and enterprises. Second, promote the competitiveness of backbone enterprises in Sichuan Province and innovate the popularization modes of the market. The last suggestion is to improve the structure of the industry and complete the construction of components supporting system to realize the healthy and sustainable development of the whole automobile industry in Sichuan Province.
\end{abstract}

Keywords—new energy automobile; industry status; supporting system

\section{INTRODUCTION}

The automobile industry is an important pillar industry of the national economy. However, with the rapid increase in the number of automobiles, the depletion of petroleum and other fossil fuels, the threat of energy and environmental pollution have become increasingly serious. In order to solve many environmental pollution problems caused by traditional fuel vehicles and promote the sound development of the automotive industry, the Chinese government has successively written new types of automobiles (hereinafter referred to as new energy vehicles) into the five-year plan for the development of the national economy, gradually replacing the traditional fuel vehicle market with new energy vehicles [1]. In the process of developing new energy, China also attaches great importance to the joint efforts of the industry, and has led the vehicle manufacturers, parts factories and scientific research institutions to conduct a more systematic study of this industry. This article analyzes the status quo of the development of new energy vehicles in Sichuan Province, addresses the problems in their development, and proposes corresponding countermeasures and recommendations in order to provide effective assistance to the province in formulating new energy vehicle development strategies and implementation measures.

\section{DeVelopment Status and TREnds of Sichuan NeW ENERGY VEHICLES}

According to the information collected by China Automotive Network, Sichuan Province currently has 65 automobile manufacturers, it covers a total of 10 categories of agricultural vehicles, off-road vehicles, trucks, special vehicles, semi-trailers, passenger cars, tractors, sedans, motorcycles, and dump trucks. With the strong support of the state and the government, the investment in the new energy automotive industry continues to rise. Under the trend of the integration of market-related resources and the continuous upgrading of the industrial structure, the proportion of new energy vehicles in the market has gradually increased [2]. The relevant data show that there are 54 new energy automobile enterprises in Sichuan Province in 2017, among them, there are more than 18 auto manufacturing companies. The production of new energy vehicles is mainly pure electric and hybrid commercial vehicles and passenger vehicles. In the whole year of 2017, Sichuan's auto production reached 1.508 million, an increase of $15 \%$ over the same period of the previous year, including 24,000 new energy vehicles, an increase of $66 \%$ year-on-year. As of the end of 2017, Chengdu's "Green Card” (referring to new energy vehicles) has 27,000 license plates. Chengdu has promoted the use of 35,000 new energy vehicles in the fields of private cars, buses and logistics vehicles, official vehicles, and sanitation vehicles [3].

Accompanied with the acceleration of construction of charging facilities, the number of newly-added charging/recharging stations in the province reached 94 in just 10 months in 2017. Currently, there are 291 stations for charging/changing power stations, and 8,688 charging stations. In response to the huge market space for new energy, according to the Sichuan Provincial Government issued the "Sichuan New Energy Vehicle Industry Development Plan (2015-2020)", it was pointed out that a national new energy automobile industrial base with Chengdu and Luzhou as the core development zones should be built, and that the province's new energy vehicle production capacity will reach 300,000 by 2020 , and 100,000 new energy vehicles will be promoted [4]. Focusing on cultivating new energy automobile companies such as Sichuan Automobile Mustang and other local brands, to form a relatively complete new energy vehicle R\&D, manufacturing, application and service system will be formed to better solve the technical bottlenecks that restrict the 
development of new energy vehicles in China. New energy is the future direction of automobile development. The development strategy of government-led new energy vehicles will be conducive to industrialization and the acceleration of industrial structure construction [5,6].

\section{OPPORTUNITIES AND CHALLENGES FOR NEW ENERGY AUTOMOTIVE INDUSTRY IN SICHUAN PROVINCE}

Sichuan Province is located in the southwest and has abundant resources. As an important industrial province, the industrial development is strong and strong. In the face of global energy transformation and the trend of China's industrial green transformation, new energy vehicles have a huge market space. As one of the national new energy automobile manufacturing and promotion bases, Sichuan plays an important role in promoting new energy vehicles to replace traditional fuel vehicles as a pillar industry.

Considering the two major aspects of energy and environmental protection, a series of preferential policies have been formulated to promote the development of the new energy automobile industry. Under the blueprint of advocating the establishment of a beautiful and harmonious new China, the new energy industry is a national of environmental protection countries. Economically important industries will usher in unprecedented opportunities for development. In 2017 Sichuan Province issued the "13th Five-Year Plan for Strategic Emerging Industries Development Plan in Sichuan Province" to issue planning and policy documents to promote the stable development of new energy vehicles. However, as people's quality of life improves and they pay more attention to the quality of their products, automobiles have entered millions of households as an important means of transportation. Under the call of the country's low-carbon environment, consumers often face conflicting psychology when purchasing new energy vehicles and traditional fuel vehicles. Although a new energy vehicle has many advantages by comparing the existing technical problems of the traditional fuel vehicles, such as lack of power and battery operating distance, consumers often fall back and forth, it is the biggest challenge for new energy vehicle technology to go to market.

\section{Problems IN The DeVElopment of NeW EnERgy VEHICLES}

As the "energy" source of new energy vehicles, power batteries have been slow to progress in the "three power" technical problems [7], which has become the focus of the development of new energy vehicles and the high purchase and maintenance costs of complete vehicle products are higher than those of conventional fuel vehicles. In addition to the late construction of supporting infrastructure (charging stations and charging piles), the development and demonstration of Sichuan's new energy automotive industry still faces many difficulties and challenges.

\section{A. Key Technologies such as Power Batteries have not Broken}

Power battery is one of the core technologies of the new energy vehicle's three power technologies. It consists of batteries, battery packs, high and low voltage wiring harnesses, protective enclosures, battery management systems, cooling systems, and other structural components [8]. As a source of power for automobiles, the driving range and lifespan of power batteries have become a key factor that restricts the introduction of new energy into the market. Three-cell lithium batteries are used for battery types, and power batteries are affected by key components such as batteries. The vast majority of automotive brands in China have only mastered the vehicle controller and three-electrical integration technology, and the core technology of the three power components is also subject to other countries. Compared to the new Tesla Model series of foreign energy, china's electric batteries have problems with short range, long charging time, short life, and battery instability. Chuanqi Yema is a new energy automobile manufacturing company in Sichuan Province. At the new energy strategy and product launch conference held in Chengdu, two pure-electric new energy vehicles, the Mustang U 350 and the Mustang E30 were unveiled [9], fast charge 1-2 hours (electricity 80\%), slow charge takes 10 hours, pure electric cruising mileage is about 250 kilometers, driving range is only half of foreign new energy vehicles, although the fast charging time is considerable, long-term use will reduce the life of the power battery. For the many problems of the power battery, only the battery pack (PACK) and the advanced battery management system (BMS) technology are currently used to make up for the defects of the power battery.

\section{B. The Company's Core Competitiveness is not Strong, and its Market Share is Low}

Product quality is the life of an enterprise and the lack of research and development capabilities is the key factor that restricts the technological breakthrough of new energy vehicles in Sichuan Province. According to statistics, there are only six R\&D centers in the Sichuan automobile industry, no national vehicle inspection and certification organizations and national vehicle $R \& D$ centers, and the number of $R \& D$ institutions and professional technicians in the automotive industry compared with first-tier cities (Shanghai and Chongqing). There is a large distance, and the lack of relevant technology R\&D and innovation capabilities [10]. Sichuan Automobile has its own shortcomings in the overall structure of the industry. For example, commercial vehicles and passenger vehicles have a similar production capacity. The market deployment demand has found that the production capacity of commercial vehicles is too large. Sichuan is a major province of industrial manufacturing, and the positioning of passenger vehicles manufactured mainly depends on the low-end products are the main products. As it is shown in the China Industry Information Network statistics of new energy vehicles, at present, sales and promotion of new energy passenger vehicles in Sichuan are mainly in Chengdu and Luzhou City, and the number of new energy passenger vehicles promoted during 2013 to 2015 was only 8,625. This period compared the promotion of 383,000 new energy vehicles across the country. The promotion was affected by many factors such as the location of the city, and the production of pure electric new energy vehicles was too low, which directly led to a low market share. 
C. The Structure of New Energy Vehicles is Irrational and the Local Matching Rate is not High

According to statistics on 22 related new energy automobile companies in Sichuan Province, it is found that half of the companies are mainly accumulating in Chengdu. The cars produced are mainly biased towards pure electric buses and special vehicles. The number of pure electric new energy passenger vehicles is small. However, only one or two new-energy automobile companies are located in cities such as Mianyang, Deyang, Yibin, Guangyuan, Guang'an, Zigong, Ya'an, Luzhou and Nanchong. The production of automobiles is mainly oriented towards low-speed and micro-electric vehicles and some passenger vehicles. Limited by regional layout, it was found that there was a lack of corresponding technical exchanges among new energy auto companies, and there were only six companies in the production of new-energy auto companies that had production models that were untidy and had high repetition rates, especially on pure electric new energy passenger vehicles. Some models have serious cross production, and there are structural irrationalities. Table I shows the Sichuan Province's new energy auto companies according to the Sichuan Provincial New Energy Vehicle Report.

TABLE I. TABLE OF NEW ENERGY AUTOMOBILE ENTERPRISES IN SICHUAN PROVINCE

\begin{tabular}{|c|c|c|}
\hline Company Name & Production type & location \\
\hline Chengdu Dayun Automobile Co.,Ltd & New Energy Electric Logistics Vehicle & Chengdu \\
\hline Zhongzhi New Energy Vehicle Co.,Ltd & Pure electric buses, logistics, RVs, etc. & Chengdu \\
\hline $\begin{array}{l}\text { Zhongzhi Yike Chengdu Automobile } \\
\text { Co.,Ltd }\end{array}$ & Pure electric bus & Chengdu \\
\hline Chengdu Bus Co.,Ltd & Pure electric and hybrid sightseeing and city buses & Chengdu \\
\hline Sichuan Yema Automobile Co.Ltd & Pure electric bus and new energy passenger car & Chengdu \\
\hline $\begin{array}{c}\text { Sinotruk Mianyang Special Vehicle } \\
\text { Co.,Ltd }\end{array}$ & LNG carrier & Chengdu \\
\hline $\begin{array}{c}\text { Chengdu Yajun New Energy Automobile } \\
\text { Technology Co., Ltd }\end{array}$ & New energy logistics vehicle and light truck R\&D & Chengdu \\
\hline $\begin{array}{c}\text { Sichuan Jiankun New Energy Automobile } \\
\text { Co., Ltd }\end{array}$ & Low-speed electric car & Chengdu \\
\hline $\begin{array}{l}\text { Sichuan Province Bus Manufacturing Co., } \\
\text { Ltd }\end{array}$ & Pure electric bus and accessories marketing & Chengdu \\
\hline FAW (Sichuan) Special Vehicle Co.,Ltd & Pure electric vehicle (junk) & Chengdu \\
\hline Sichuan Yema Automobile Co.Ltd & New energy passenger car & Mianyang \\
\hline Mianyang Huarui Automobile Co., Ltd & Car modification and accessories marketing & Mianyang \\
\hline Sichuan New Century Electric Vehicle & Powertrain technology research and development & Guangyuan \\
\hline $\begin{array}{c}\text { Sichuan Sida Automobile Manufacturing } \\
\text { Co., Ltd }\end{array}$ & Refitting and parts production & Guangyuan \\
\hline $\begin{array}{c}\text { Sichuan Jindi New Energy Technology } \\
\text { Co., Ltd }\end{array}$ & Miniature pure electric car & Deyang \\
\hline $\begin{array}{l}\text { Geely Sichuan Commercial Vehicle Co., } \\
\text { Ltd }\end{array}$ & Refitting and automotive parts & Nanchong \\
\hline $\begin{array}{c}\text { Luzhou Haoyu New Energy Automobile } \\
\text { Co., Ltd }\end{array}$ & Low-speed electric car (tourist car) & Luzhou \\
\hline $\begin{array}{l}\text { Yibin City Tengchuan Automobile Co., } \\
\text { Ltd }\end{array}$ & Electric special vehicle manufacturing & Yibin \\
\hline $\begin{array}{c}\text { Sichuan Tianfei Nidi New Energy } \\
\text { Technology Co., Ltd }\end{array}$ & Low-speed electric vehicle $R \& D$ & Zigong \\
\hline $\begin{array}{c}\text { Sichuan Construction Lijue New Energy } \\
\text { Automobile Co., Ltd }\end{array}$ & Mini electric vehicle & Guangan \\
\hline $\begin{array}{c}\text { Sichuan Xinzhutonggong Automobile } \\
\text { Co., Ltd }\end{array}$ & Pure electric bus & Yaan \\
\hline Sichuan Yingma Electric Vehicle Co., Ltd & Low-speed electric car & Yaan \\
\hline
\end{tabular}

As one of the core promotion bases for new energy vehicles, Chengdu currently has 10 vehicle manufacturing plants, most of which are engaged in the production of traditional passenger cars, trucks, and construction vehicles. Representing Sichuan Automobile's Mustang as a representative of new energy passenger vehicles, FAW (Sichuan) Special Purpose Vehicle Co., Ltd. mainly produces garbage trucks and sprinklers on pure electric new energy vehicles, facing the powerful new energy automotive market environment in the western region. Comparing the structure of new energy auto companies in the province, the cost structure of new energy vehicles was analyzed. There were four local conversion and spare parts manufacturers. The province's spare parts and power batteries were mainly provided for
Note: This table is based on the report of Sichuan Provincial New Energy Vehicle.

low-speed electric vehicles and buses. Vehicle components and power batteries rely mainly on foreign provinces and foreign countries, showing a low rate of matching.

On the one hand, Sichuan Province ranks the development of new energy automotive industry as a "13th Five-Year" strategic emerging industry development. From the policy support, in the face of the technical problems of new energy vehicles and the powerful traditional fuel vehicle market, enterprises are more inclined to invest in research and development of traditional fuel vehicles that are effective and have good returns. Auto companies invest some funds under the conditions of ensuring good returns to develop energy vehicles. Insufficient investment in R\&D expenditures restricts the development of a series of related industries such 
as research and development of key components of new energy vehicles, basic charging facilities, and marketing promotion. On the other hand, the relevant data shows that the auto industry's local parts and components matching rate is less than $40 \%$, showing that the local matching rate is low, which is the status quo of Sichuan's vehicle manufacturing industry. In addition, the ratio of the output value of the whole vehicle to the production value of parts and components is 1:0.9, which compares with the average international production value. The ratio of $1: 1.7$ can be easily derived and the supporting development is not balanced [11] (see Figure I).

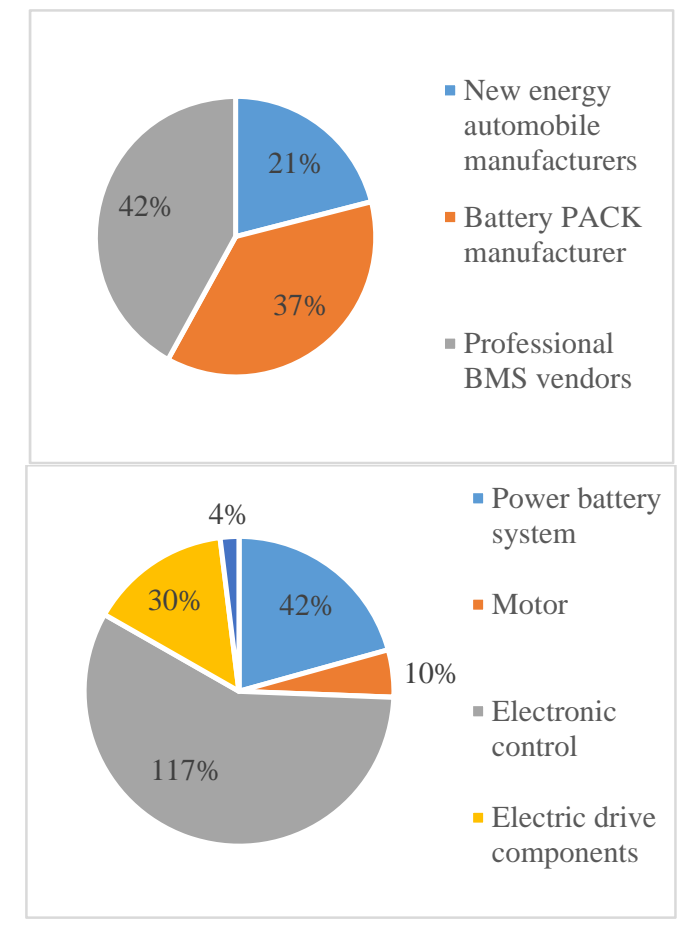

FIGURE I. NEW ENERGY VEHICLE COST STRUCTURE

\section{COUNTERMEASURES AND SUGgESTIONS FOR ACCELERATING THE DEVELOPMENT OF NEW ENERGY AUTOMOBILE INDUSTRY IN SICHUAN PROVINCE}

A. Government Leads, School-Enterprise Cooperation, Breakthrough Core Technology

Sichuan Province currently has 985,211 universities in China, such as Sichuan University and Southwest Jiaotong University, and the State Key Laboratory of Vehicle Engineering at Xihua University. The new energy automobile industry is the seven major industries, high-end growth industries, and the thirteenth five-year strategic emerging industries in Sichuan's “ $7+7+5$ " industrial system layout, the government as the lead agency should take the initiative to lead the school-enterprise cooperation. Enterprise schools and research institutes should build new energy innovation and $\mathrm{R} \& \mathrm{D}$ platforms. Based on the province's auto production capacity and actual market demand, it integrates the research and development resources of universities and corporations, introduces high-end R\&D teams, and builds provincial new energy automobile innovation institutes to attract high-end technical talents from the national automotive industry to gather in Sichuan and promote the conversion of superior technologies in Sichuan [12,13]. Research and development of new international advanced new energy vehicle models, breakthrough in the independent brand vehicle control and the three power control core technologies, especially the research and development of the three power component technologies, improve the power battery due to technical defects in the core components and restrict its development, improve the whole Provincial innovative research and development capabilities.

\section{B. Upgrade the Competitiveness of Backbone Enterprises in} Sichuan and Create Innovative Marketing Models

Chuanqi Mustang, as a local new energy automobile company, has more than 10 years of research and development of new energy vehicles, and has already had relatively advanced new energy automotive technologies in China. The government should seize the corporate radiation and driving role to promote, its development of new energy automotive industry. Sichuan Province should increase its support for new energy vehicles $R \& D$ backbone enterprises and help them establish market competitiveness. Enterprises should strengthen technical communication and exchanges. In the interest of protecting the interests of all parties in advance, strengthen technical cooperation and promote the development of key technologies for new energy vehicles. Product improvement is a necessary process. In the bottleneck period of new energy automotive technologies such as power batteries, more attention should be paid to the promotion and innovation of product business models, and active changes in consumer target positioning should be introduced to target different groups of people. In the market, R\&D companies have enough funds to invest in product R\&D through consumer feedback.

\section{Optimizing the Industrial Structure and Improving the Component Supporting System}

Under the guidance of the "Three Goes, One Downs, and One Compensation” in the country, Sichuan Province should identify the orientation of the new energy automobile industry, take the initiative to adjust and optimize the industrial structure, Improve the proportion of commercial vehicles and passenger cars, and increase the proportion of new energy vehicles in total vehicle output. It can learn from the operating models of new energy automobile auto companies like Tesla from abroad, learn about their reasonable industrial layout, take the initiative to carry out technological transformation and upgrading, and adjust the product structure while reinforcing the shortcomings of the industry. Optimize the cost components of new energy vehicles such as powertrain (50\%), chassis (14\%), body-in-white (5\%), interior (15\%), electronics (9\%), and other (7\%). Strengthen the province's own brand of new energy vehicles. In addition, the automobile manufacturers of compact cars will improve their supporting systems for their parts and components, promote the open and localized development of their supporting systems, and further improve the supporting level.

\section{REFERENCES}

[1] Li Dayuan. Research on the Development of China's New Energy Automobile Industry under the Background of Low-carbon Economy[J]. Economic Review, 2011(02):72-75. 
[2] Tang Yijun, Liu Jiangpeng. Prospects for the development of China's new energy automotive industry [J]. Journal of Beijing Institute of Technology (Social Sciences Edition), 2015, 1702: 1-6.

[3] Sichuan Province New Energy Vehicle Market Report [EB/OL]. (2018.3.29) [2018.05.04]. https://wenku.baidu.com/view/e406fe15ae45b307e87101f69e314332396 8f5f2.html.

[4] China News, Oriental Fortune Network. "Sichuan made" new energy auto debut at Chengdu New Energy Auto Show [DB/OL]. [2018.05.05] http://finance.eastmoney.com/news/1355, 20180505867378059.html.

[5] Guan Qi. Research on Domestic New Energy Vehicle Industry Development and Competitive Strategy[D]. University of International Business and Economics, 2017.

[6] Yuan Bo. Research on the Development Strategy and Path of China's New Energy Automobile Industry[J]. Regional Economic Review, 2017(06):126-134.

[7] Li Rui. Research on the status quo of development of new energy automobile industry in Jiangsu Province and its countermeasures[D]. Wuhan University of Engineering, 2017.

[8] Chen Wenbo. Key technologies and development bottlenecks of new energy vehicles in China [J]. Traffic Standardization, 2011(19): $172-173+167$

[9] The reporter Zhao Zhangdong. Can Mustang pick up the "Chuan Zihao" new energy car banner?[N]. Sichuan Daily, 2017-08-10014.

[10] Cai Yun, Huang Chaoyang, Li Qingsong. Analysis and Research on the Development of Sichuan Automobile Industry[J]. Western Economic Management Forum, 2011,22(01):36-40.

[11] China Electric Vehicles Network, Industry News. Sichuan's production capacity of new energy vehicles will reach 300,000 units by 2020 [DB/OL]. (2017.09.26) [2018.04.05]. http://auto.qq.com /a/20170929/024139.htm.

[12] Chen Ge. Research on the influence of supporting policies on the development of new energy auto industry [D]. Shandong University, 2017.

[13] Hu Maoyuan. A Good Policy to Guide the Healthy Development of the Automotive Industry [J]. Automotive Industry Research, 2004 (07): $17-18$ 